\title{
JAKI PODRĘCZNIK DO NAUKI RELIGII DLA MŁODZIEŻY W XXI WIEKU?
}

\section{WSTĘP}

Zagadnienie podręczników do nauki religii w polskiej szkole jest od kilku lat żywo dyskutowane wśród teoretyków i praktyków katechezy ${ }^{1}$. Wprowadzenie w roku szkolnym 2009/2010 nowej Podstawy kształcenia ogólnego ${ }^{2}$ spowodowało potrzebę opracowania nowej Podstawy programowej katechezy Kościoła katolickiego w Polsce 3 i Programu nauczania

* Beata Bilicka - dr hab. nauk teologicznych w zakresie katechetyki; adiunkt w Zakładzie Katechetyki i Pedagogiki Religii na Wydziale Teologicznym UMK w Toruniu; diecezjalny wizytator katechizacji; ekspert MEN do spraw awansu zawodowego nauczycieli, rzeczoznawca Komisji Wychowania Katolickiego Konferencji Episkopatu Polski do spraw oceny programów nauczania religii i podręczników katechetycznych.

${ }^{1}$ Zob. J. Kostorz, Podręczniki do nauki religii sens czy bezsens? Materiaty sympozjum naukowego zorganizowanego przez Katedre Katechetyki, Pedagogiki i Psychologii Religii Wydziału Teologicznego UO Opole, 25 kwietnia 2009, (Seria: Sympozja, nr 78), Opole 2009.

${ }^{2}$ Zob. Rozporzadzenie Ministra Edukacji Narodowej z dnia 23 grudnia 2008 r. w sprawie podstawy programowej wychowania przedszkolnego oraz kształcenia ogólnego w poszczególnych typach szkót, Dziennik Ustaw z dnia 15 stycznia 2009 r. Nr 4, poz. 17.

${ }^{3}$ Podstawa została przyjęta podczas 351. zebrania plenarnego Konferencji Episkopatu Polski w Warszawie w dniu 8 marca 2010 r. "Stara" podstawa programowa (2001 r.) 
religii ${ }^{4}$ oraz nowych podręczników. Pytanie o podręcznik do nauki religii dla młodzieży jest zatem bardzo aktualne i uzasadnione.

W literaturze, zwłaszcza pedagogicznej, odnaleźć możemy wiele definicji podręcznika. Powszechnie uznawany jest on za podstawowe narzędzie dydaktyczne używane zarówno przez ucznia, jak i nauczyciela. Nas interesować będzie podręcznik dla ucznia, który za J. Szpetem definiujemy jako „celowo ukierunkowany układ materiałów dydaktyczno-wychowawczo-inicjacyjnych, odpowiadający założeniom tematycznym rocznego programu kształcenia ${ }^{5}$, prezentujący najnowsze jasno sformułowane i uporządkowane treści przedstawione za pomocą słów i sposobów graficznych (fotografii, obrazów, map, diagramów, wykresów), problemów do rozwiązania, inspiracje motywacji i postaw, ćwiczenia i zadania praktyczne zgodnie z wyznaczonymi celami kształcenia i zasadami dydaktycznymi, formami i metodami nauczania; służący też kontroli i ocenie wyników"6.

W poszukiwaniu odpowiedzi na pytanie postawione $\mathrm{w}$ tytule naszego artykułu należy uwzględnić fakt, iż żyjemy w czasach rozwijającej się w wielkim tempie technologii informacyjnej i komunikacyjnej, w czasach kiedy stale rozwijający się Internet ma bardzo duży wpływ na styl życia młodego pokolenia, na to jak ono się uczy, komunikuje i współpracuje ze sobą. Z tego też względu Internet powinien zostać wykorzystany także w szkolnym nauczaniu religii.

będzie obowiązywać do 31 sierpnia 2016 r., a „nowa” (2010 r.) zacznie funkcjonować w klasach pierwszych szkoły podstawowej od 1 września 2012 r.

${ }^{4}$ Nowy program przyjęty 9 czerwca 2010 r. ukazał się w księgarniach pod koniec września $2010 \mathrm{r}$.

${ }^{5}$ Poza książkami do nauki religii, które są całkowicie i równolegle skorelowane z programem nauczania, wyróżnić można inne formy podręcznika takie jak: podręcznik tematyczny, książka do czytania, książka do nauki religii ukierunkowana tematycznie; por. J. Bagrowicz, O teorii i praktyce recenzowania podręczników, w: red. P. Tomasik, W trosce o dobre podręczniki, Kraków 2003, s. 32-33.

${ }^{6}$ J. Szpet, Podręcznik w katechezie, w: red. R. Chałupniak, J. Kochel, J. Kostorz, W. Spyra, Wokót katechezy posoborowej, Księga pamiątkowa dedykowana Ks. Biskupowi Gerardowi Kuszowi, wykładowcy Wydziatu Teologicznego Uniwersytetu Opolskiego z okazji 65. rocznicy urodzin, Opole 2004, s. 330-331. Krótszą definicję podręcznika do nauki religii podaje A. Długosz: „Podręcznik stanowi wypisy biblijne, liturgiczne, egzystencjalne. Stanowi zbiór modlitw, pieśni, piosenek, posiada materiały wizualne oraz powtórkowe zestawy ćwiczeń. Jest także skróconym katechizmem. $Z$ tej racji możemy go w różnoraki sposób wykorzystywać, realizując szeroki wachlarz metod"; A. Długosz, Jak przygotowywać i oceniać katechezę, Elementy dydaktyki katechetycznej, Częstochowa 1997, s. 35-36. 
Nasze rozważania - z konieczności ograniczone - stanowią zaledwie przyczynek do szerszej dyskusji na temat podręcznika do nauki religii dla młodzieży. Przedstawimy je w czterech częściach. W pierwszej wskażemy na jedno z ważnych uwarunkowań współczesnego nauczania religii, a mianowicie coraz częściej pojawiającą się niechęć uczniów do korzystania z papierowych książek. Następnie opiszemy podstawowe funkcje tradycyjnego podręcznika, aby w kolejnej części - w nawiązaniu do tych funkcji - wskazać na możliwość opracowania nowej formy książki do nauki religii dla młodzieży wykorzystującej możliwości, jakie daje komputer i Internet. Całość wieńczyć będzie krótkie zakończenie.

\section{PRZYCZYNY NIECHĘCI UCZNIÓW DO KORZYSTANIA Z PAPIEROWYCH KSIĄŻEK}

Od kilku lat jesteśmy świadkami prawdziwej rewolucji informacyjnej i komunikacyjnej, której głównym motorem jest Internet ${ }^{7}$. Oferuje on wiele usług między innymi zdalne logowanie się użytkowników, przesyłanie plików, pocztę elektroniczną, World Wide Web (WWW), grupy dyskusyjne $^{8}$ i wiele innych. O ile rozwój dotychczasowych sposobów komunikowania się przebiegał raczej wolno i w sposób ewolucyjny, to Sieć rozwija się $\mathrm{w}$ ekspresowym tempie, stając się narzędziem powszechnym i bardzo popularnym. Ogólny dostęp do Internetu w XX i XXI wieku przyczynił się do tego, iż dla młodych ludzi nowe technologie nie stanowią już wyzwania, ale są zwykłą codziennościąa . Na szkolne lekcje religii przychodzą dzisiaj młodzi ludzie, którzy urodzili się i wzrastają w czasach powszechnego stosowania technik informacyjnych, są one dla nich dziedziną zastaną i oczywistą. Komputery, telefony komórkowe, różne elektroniczne zabawki towarzyszą im już od urodzenia, dlatego bez trudu potrafią korzystać z najnowszych rozwiązań technologicznych.

Nieustannie rozwijająca się Sieć ma bardzo duży wpływ na zmiany w stylu naszego życia, pracy, sposobu uczenia się, komunikowania i wzajemnej współpracy. Zmienia się także model jednostki lekcyjnej,

7 Za A. Niwińskim słowa Internet oraz Sieć piszemy wielką literą; zob. A. Niwiński, Środki informatyczne w katechetycznej działalności Kościoła, Kraków 2004, s. 9.

${ }^{8}$ Por. B. Pfaffenberger, Stownik terminów komputerowych, Warszawa 1999, s. 111.

9 Por. B. Drążkowska, Rola katechety w społeczeństwie informacyjnym, „Katecheta” 51 (2007) nr 7-8, s. 115. 
ponieważ młodzież wychowywana w otoczeniu urządzeń cyfrowych (np. aparat cyfrowy, kamera cyfrowa, odtwarzacz MP3, telefon komórkowy, komputer, radio internetowe i wiele innych) wymaga innego podejścia pedagogicznego, aniżeli kilka lat temu, kiedy podstawowymi pomocami dydaktycznymi był podręcznik i tablica, po której pisało się białą kredą. Jak dotąd uczeń był przede wszystkim biernym odbiorcą przekazywanej mu przez nauczyciela wiedzy, którą mógł uzyskać w zasadzie tylko od niego lub z książek. Powszechny niemal dostęp do Sieci i łatwość w posługiwaniu się przeglądarkami internetowymi sprawił, że dzisiaj wiele informacji uczeń potrafi pozyskać samodzielnie, nie korzystając przy tym z zasobów bibliotecznych czy z wiedzy swojego nauczyciela. „Dzisiaj nie ma potrzeby - zdaniem M. Polaka - wiedzieć wszystkiego z danego przedmiotu. Jeśli nie wiem, mam wyszukiwarkę i jestem w stanie się dowiedzieć w kilka minut"10.

Tradycyjny model lekcji nie interesuje już młodzież, ponieważ jest przyzwyczajona do interaktywności, do pracy z komputerem, który domaga się natychmiastowej reakcji użytkownika. Młodzi posiadają także „umiejętność obsługi wielozadaniowych gier komputerowych, prowadzenia w Internecie rozmów ze swymi przyjaciółmi i realizowania własnych pomysłów - wszystko w tym samym czasie. Szkoła ani nie dostarcza im tylu bodźców równocześnie, ani nie daje takiej możliwości wyboru tematu"11. Uczniowie nie chcą uczyć się na pamięć definicji czy dat, ponieważ nie widzą w tym sensu, skoro w kilka sekund mogą tego typu informacje odnaleźć w Internecie, tym bardziej, że wielu z nich ma prawie nieograniczony dostęp do Sieci, ponieważ coraz częściej nosi przy sobie netbooki lub smartfony.

Niemały wpływ na zmieniający się model lekcji mają tablice interaktywne, które pomagają nauczycielom zaangażować młodzież w lekcję oraz stworzyć im środowisko, w którym uczniowie mogą w procesie nauczania-uczenia się wykorzystywać swoje indywidualne preferencje i zdolności. W wielu szkołach tego typu tablice zastąpiły już tablice tradycyjne, po których pisało się kredą. Tablice interaktywne mogą bawić i uczyć, przez co dają nauczycielowi możliwość przedstawienia materiału w sposób ciekawy i urozmaicony, sprawiając jednocześnie, że jego praca staje się łatwiejsza i przyjemniejsza. Ponadto tablice interaktywne wpro-

10 A. Kowalski (red.), Dwa lata non-stop o edukacji, [dostęp 25.08.2010], http:// edunews.pl/index.php?option=com_content\&task=view\&id=1121\&Itemid=9.

11 A. Niwiński, dz. cyt., s. 204. 
wadzają do klas swego rodzaju "teatralne napięcie” i powodują, że „świat zewnętrzny zostaje zaproszony na lekcje prosto do klasy szkolnej"12. Odpowiednio wykorzystane przez nauczycieli mogą w pozytywny i znaczący sposób wpłynąć na proces nauczania-uczenie się. Zdaniem M. Nowak „Tablice interaktywne to tylko jedno z wielu narzędzi, jakie zaczyna być powszechnie wykorzystywane w szkołach. Producenci oprogramowania i sprzętu cały czas pracują nad nowymi technologiami interaktywnej edukacji. Możemy się spodziewać narzędzi bardziej spersonalizowanych lub przeznaczonych specjalnie do pracy w grupie"13.

Coraz częściej duży problem dla wielu młodych ludzi stanowi tradycyjna książka czy szkolny podręcznik; przyzwyczajeni są bowiem do natychmiastowego odnajdywania informacji w Sieci, dlatego przeszukiwanie drukowanej encyklopedii lub słownika staje się dla nich trudnym, nudnym i czasochłonnym zadaniem. Wolą pracę on-line lub encyklopedie na płytach CD, które pozwalają szybko i skutecznie odnaleźć potrzebne wiadomości. Wielu uczniom łatwiej jest poruszać się w Sieci, aniżeli w bibliotece, która znajduje się w realnym świecie. Łatwiej przecież i szybciej można posłużyć się przeglądarką internetową, aniżeli tradycyjnym indeksem, uzyskać informację ze stron WWW, aniżeli z papierowego podręcznika ${ }^{14}$. $\mathrm{Z}$ też tego względu przeszukiwanie tradycyjnych książek traktują jako stratę czasu. Zdaniem B. Drążkowskiej „Jest to pokolenie nastawione na stałe odbieranie pobudzających bodźców, bardzo ambitne, nie potrafiące egzystować poza strumieniem informacji, który jednocześnie męczy je, a z drugiej strony pociąga. Jest to swoistego rodzaju twór wyrosły w cyberprzestrzeni, bez której nie jest w stanie poprawnie funkcjonować"15.

Warto w tym miejscu zwrócić uwagę na wyszukiwarki internetowe np. Google, które stanowią potężne narzędzie i najlepszy oraz najprostszy sposób odnajdywania informacji w Internecie. Niestety, wykorzystanie ich w nieumiejętny sposób może prowadzić do uzyskania niepełnych danych.

${ }^{12}$ M. Nowak, Tablice interaktywne w procesie nauczania, [dostęp 23.08.2010], http:/ / edunews.pl/index.php?option=com_content\&task=view\&id=169\&Itemid=15. Autorka artykułu zwraca uwagę na fakt, iż mimo posiadania tablicy interaktywnej, bardzo często „nauczyciel nadal znajduje się w centrum procesu nauczania i kieruje bezpośrednio przekazem wiedzy. Nie jest to spowodowane niedoskonałościami technologii, lecz brakiem odpowiedniego przygotowania pedagogicznego nauczycieli do korzystania z tablic multimedialnych".

13 Tamże.

14 Por. A. Niwiński, dz. cyt., s. 204.

${ }^{15}$ B. Drążkowska, dz. cyt., s. 116. 
Wielu nauczycieli zauważa, że młodzież nie potrafi korzystać z zaawansowanych sposobów wyszukiwania, często ograniczając się do wpisywania w pasku adresu przeglądarki tylko słów kluczowych, co z kolei może spowodować zawężenie wyszukiwania do strony o danym adresie. Innymi niepokojącymi zjawiskami są: bouncing - szybkie przeglądanie kolejnych wyników wyszukiwania, bez wnikliwego czytania całych tekstów oraz print-mania, czyli drukowanie wszystkiego, co można odnaleźć w Internecie na dany temat, nawet tego, czego nie zamierza się później przeczytać16.

Przemiany zachodzące $w$ mentalności młodych ludzi, między innymi pod wpływem powszechnego wykorzystania komputerów i Internetu, domagają się uznania potrzeb uczniów za szczególnie ważne, a to oznacza konieczność zweryfikowania dotychczasowej praktyki i metod nauczania, także $\mathrm{w}$ zakresie pracy z podręcznikiem. Zmieniające się dziś sposoby pozyskiwania informacji stanowią niemałe wyzwanie dla nowej dydaktyki, zwanej często dydaktyką epoki cyfrowej ${ }^{17}$. Także metodyka nauczania religii musi je dostrzec i dobrze wykorzystać.

W świetle tego, co już zostało powiedziane można zadać pytanie: skoro papierowy podręcznik, także podręcznik do nauki religii, postrzegany jest często przez młodzież jako „nieatrakcyjny” i przegrywa $\mathrm{z}$ „atrakcyjnym” multimedialnym (tekst, dźwięk, grafika, animacja, wideo) Internetem, to czy $\mathrm{w}$ tradycyjnej formie jest on dzisiaj jeszcze potrzebny? Zanim spróbujemy odpowiedzieć na to pytanie, wskażemy na podstawowe funkcje, jakie spełniać powinna tradycyjna, papierowa książka do nauki religii.

\section{FUNKCJE TRADYCYJNEGO PODRĘCZNIKA DO NAUKI RELIGII}

Dydaktycy wskazują na różne funkcje podręcznika, spośród których - zdaniem J. Szpeta - wyodrębnić można cztery podstawowe:

${ }^{16}$ Por. A. Pietras (red.), Co mtodzi ludzie wiedza na temat nowych technologii?, [dostęp 23.08.2010], http://edunews.pl/index.php?option=com_content\&task=view\&i$\mathrm{d}=1192 \&$ Itemid $=14$.

${ }^{17}$ Dydaktyka epoki cyfrowej „interesuje się dziś przede wszystkim badaniem: ludzkich potrzeb $\mathrm{w}$ zakresie uczenia się w szkole i pracy; organizacji zajęć $\mathrm{z}$ wykorzystaniem zasobów Internetu; kluczowych (życiowych, potrzebnych) kompetencji potrzebnych w epoce cyfrowej; nowoczesnych strategii, metod pracy i form organizacyjnych e-edukacji; strategii, technik i narzędzi sprawdzania oraz oceniania efektów internetowego uczenia się itp."; J. Sawiński, O dydaktyce epoki cyfrowej, [dostęp 23.08.2010], http:/ /www. edunews.pl/index.php?option=com_content\&task=view\&id=1151\&Itemid=1. 
- informacyjną,

- badawczą,

- praktyczna,

- samokształceniową.

Funkcje te powinien spełniać także podręcznik do nauki religii, który - ze względu na cel i zadania katechezy ${ }^{18}$ - należy rozbudować o funkcję wychowawczo-inicjacyjną ${ }^{19}$. Opiszemy je krótko, wskazując na możliwość ich realizacji w podręczniku do religii.

1. Funkcja informacyjno-poznawcza uznawana za zasadniczą i najważniejszą oznacza, iż podręcznik stanowi przede wszystkim przewodnik w poznawaniu prawdy. Jest realizowana przez dostarczenie uczniom usystematyzowanej wiedzy religijnej oraz zapoznawanie ich z prawdami naszej wiary. Przekazywana wiedza nie powinna posiadać skończonej formy, ale pobudzać katechizowanych do dalszych poszukiwań ${ }^{20}$. Funkcja informacyjno-poznawcza posiada charakter służebny wobec wiary, która jest wewnętrznym aktem i stanowi cel działań katechetycznych. Przekazywane na katechezie „prawdy historii zbawienia domagają się poznanie, zrozumienie, by dzięki temu możliwe było przylgnięcie do Chrystusa"21. Należy więc pamiętać, że informacja jest - jak zauważa P. Tomasik fundamentem dla właściwie prowadzonej formacji chrześcijańskiej ${ }^{22}$. Nie można w katechezie pominąć pewnego zasobu wiedzy, która musi być opanowana przez uczniów; mówił o tym wyraźnie Jan Paweł II w Adhortacji apostolskiej Catechesi tradendae: „Przyswojenie pamięciowe słów Jezusa, ważnych tekstów biblijnych, Dekalogu, formuł wyznania wiary, tekstów liturgicznych, ważniejszych modlitw, głównych prawd nauki chrześcijańskiej nie tylko nie uwłacza godności młodych chrześcijan, ani nie stanowi przeszkody w osobistym dialogu $\mathrm{z}$ Bogiem, ale jest nawet prawdziwą koniecznością. [...] Oczywiście jest rzeczą bardzo ważną, by

18 „Katecheza jest wychowaniem we wierze dzieci, młodzieży i dorosłych, a obejmuje przede wszystkim nauczanie doktryny chrześcijańskiej, przekazywane na ogół w sposób systematyczny i całościowy, dla wprowadzenie wierzących w pełnię życia chrześcijańskiego"; Jan Paweł II, Adhortacja apostolska o katechizacji w naszych czasach "Catechesi tradendae", Watykan 1979, nr 18. Dalej stosuję skrót CT.

${ }^{19}$ Por. J. Szpet, Dydaktyka katechezy, Poznań 1999, s. 248. J. Bagrowicz przyjmując klasyfikację T. Parnowskiego wymienia z kolei funkcje: informacyjną, kształcącą, organizacyjną, wychowawczą: por. J. Bagrowicz, dz. cyt., s. 33-35.

${ }^{20}$ Por. J. Bagrowicz, dz. cyt., s. 33.

${ }^{21}$ J. Szpet, dz. cyt., s. 248.

${ }^{22}$ Por. P. Tomasik, Podręcznik w edukacji religijnej młodzieży, w: red. S. Dziekoński, Dydaktyka w stużbie katechezy, Kraków 2002, s. 253. 
te wyuczone na pamięć teksty zostały jednocześnie wewnętrznie przyswojone, stopniowo zgłębione umysłem, tak by stały się źródłem osobistego i wspólnotowego życia chrześcijańskiego" (CT 55). Źródłem informacji w podręczniku jest nie tylko tekst (słowa, opisy, wyjaśnienia, definicje), ale również forma graficzna i artystyczna książki ${ }^{23}$, na którą składają się zdjęcia, rysunki, tabelki, schematy, diagramy, wykresy.

2. Funkcja badawcza podręcznika, przez J. Bagrowicza zwana kształcąca, pozwala uczniom poszukiwać odpowiedzi na pytania dotyczące otaczającej rzeczywistości. Domaga się ujęcia treści w sposób problemowy, stawiania wielu pytań, aby w ten sposób pobudzać katechizowanych do twórczego działania i samodzielnego myślenia ${ }^{24}$. W odniesieniu do nauki religii funkcji tej służy analiza tekstów źródłowych, przede wszystkim Pisma Świętego, dokumentów Soboru Watykańskiego II, nauczania papieskiego, Katechizmu Kościoła Katolickiego, a także „wypisów z dokumentów bezpośrednio związanych z omawianym problemem, jak i analiza kontekstu powstania tekstu, samodzielna analiza tekstu literackiego oparta na jego przeżyciu"25. Kształtowanie w uczniach postawy badawczej pełni - adekwatnie do ich wieku i możliwości - istotne znaczenie na każdym etapie kształcenia, dlatego w podręczniku i na katechezie nie może zabraknąć analizy tekstów źródłowych, które pomogą uczniom w dociekaniu prawdy.

3. Funkcja praktyczna (operacyjna), zwana także funkcją transformacyjna, dotyczy praktycznych konsekwencji poznawanych prawd, dlatego wiąże się z umiejętnością przetwarzania przez katechizowanych poznawanego świata i praktykowania na co dzień swojej wiary. Podręcznik do nauki religii spełnia tę funkcję wówczas, gdy kształtuje postawy w celu doprowadzenia dzieci i młodzieży do pełnego uczestnictwa we wspólnocie Kościoła oraz do dawania świadectwa życia apostolskiego i misyjnego, a także wskazuje na możliwości podejmowania służby na rzecz drugiego człowieka. Ze względu na nadrzędny cel katechezy, jakim jest doprowadzenie do spotkania z Jezusem Chrystusem, a nawet głębokiej z nim zażyłości ${ }^{26}$, funkcję praktyczną należy uznać za wyjątkowo

${ }^{23}$ Por. tamże.

${ }^{24}$ Por. J. Bagrowicz, dz. cyt., s. 34.

${ }^{25}$ J. Szpet, dz. cyt., s. 249.

${ }^{26}$ „Ostatecznym celem katechezy jest doprowadzić kogoś nie tylko do spotkania z Jezusem Chrystusem, ale do zjednoczenia, a nawet głębokiej z Nim zażyłości. Bo tylko On sam może prowadzić do miłości Ojca w Duchu Świętym i do uczestnictwa w życiu Trójcy Świętej" (CT 5). 
ważną. Trzeba bowiem pamiętać, że na lekcjach religii chcemy przede wszystkim kształtować osobę dojrzałą we wierze, a nie osobę, która posiada tylko wiedzę o Jezusie i Jego Kościele ${ }^{27}$.

4. Funkcję samokształceniową realizuje podręcznik wówczas, gdy jego treści nie tylko budzą i rozwijają w uczniach zdolności poznawcze i zainteresowania, ale również motywują do uczenia się oraz wdrażają do samodzielnej pracy. W odniesieniu do podręcznika do nauki religii funkcję tę spełnia książka, która jest w stanie rozbudzić wśród uczniów zainteresowanie problematyką religijną oraz wywoływać pozytywną motywację do dalszego pogłębiania poznawanych prawd wiary. „Oczekiwania te - zdaniem J. Szpeta - spełnia podręcznik poprzez dobór treści kształcenia umiejętnie kształtując zainteresowania, łączenie teorii z praktyką, bogactwo oferowanych otwartych sytuacji, które zaciekawiają i pobudzą do samodzielnego poszukiwania rozwiązań i przeżywania wartości, wskazanie literatury pogłębiającej i poszerzającej zagadnienie"28. Funkcja ta łączy się ściśle z funkcją ewangelizacyjną nauczania religii, aczkolwiek należy pamiętać, że funkcję ewangelizacyjną katechezy realizują także inne funkcje podręcznika. Specyficzne znaczenie ewangelizacyjne podręcznika należy widzieć w tym, iż po książkę do nauki religii mogę przecież sięgnąć także inni członkowie rodziny ucznia ${ }^{29}$.

5. Funkcja inicjacyjno-wychowawcza to charakterystyczna funkcja książki do nauki religii, którą spełnia, gdy kształtuje przekonania i postawy moralne czytelników. Nośnikiem wartości moralnych może być fragment dzieła literackiego umieszczony w podręczniku, biografia konkretnej osoby lub określony czyn ${ }^{30}$. Należy jednak pamiętać, że podręcznik nie może grzeszyć tanim dydaktyzmem, moralizatorstwem i negatywizmem moralnym. „Warstwa wychowawcza podręcznika jak zauważa J. Bagrowicz - powinna być wyraźnie obecna, ale niejako na drugim planie, jej obecność nie może być natrętna, nużąca. Ma ona zachęcać do osobistej refleksji nad życiem, nad wiarą, stosunkiem do innych ludzi, nad sposobem obecności w społeczności. Podręcznik, który wszystko rozstrzyga z góry, niejako magisterialnie, który nie zaprasza

${ }^{27}$ Por. K. Maciejewska, Podręcznik - pomoc czy zbędny środek dydaktyczny, w: red. J. Szpet, D. Jackowiak, Katecheza, rodzina, parafia i szkoła, t. 3 - O skuteczniejszg katecheze, Poznań 2005, s. 26.

${ }^{28}$ J. Szpet, dz. cyt., s. 250.

${ }^{29}$ Por. P. Tomasik, dz. cyt., s. 257.

${ }^{30}$ Por. J. Szpet, dz. cyt., s. 250. 
do rozmowy, dyskusji, nie będzie akceptowany przez młodzież"31. Dlatego celu inicjacyjno-wychowawczego nie może realizować podręcznik, który nie stwarza możliwości dialogu między nim a katechizowanymi, ma on bowiem inspirować, a nie decydować. Książka do nauki religii będzie o tyle skuteczna, o ile będzie w stanie realizować funkcję formacyjną ${ }^{32}$.

6. Funkcję kontrolną realizują polecenia, zadania, pytania, które najczęściej umieszczone są w podręczniku na końcu tematu, bloku tematycznego czy działu i dotyczą zakresu zdobytych przez uczniów wiadomości oraz umiejętności, z zachowaniem jednak właściwych dla nich proporcji. Wykorzystanie tej funkcji może mieć miejsce podczas szkolnej lekcji religii, najczęściej pod nadzorem nauczyciela, albo w czasie samodzielnej pracy ucznia w domu - wówczas podręcznik powinien pełnić funkcję autokontrolą, samooceniającą i autokorektywną ${ }^{33}$. Funkcja kontrolna podręcznika do nauki religii dotyczy nie tylko osiągnięć zapisanych w programie, ale także wewnętrznych postaw ucznia, które powinien oceniać on sam. Zgodnie z Zasadami oceniania osiagnięć edukacyjnych z religii rzymsko-katolickiej w szkołach ocenianiu podlegają tylko wiadomości i umiejętności, a nie praktyki religijne ${ }^{34}$. Z tego też względu podręcznik powinien pobudzać katechizowanych do autorefleksji i autokorekty, powinien zawierać elementy rachunku sumienia, które nie mogą podlegać zewnętrznej ocenie dokonywanej przez nauczyciela ${ }^{35}$.

Opisane w zarysie funkcje podręcznika wzajemnie się uzupełniają i z punktu widzenia dydaktyki uzasadniają jego przydatność w procesie nauczania-uczenia się ${ }^{36}$. Z kolei z perspektywy młodego człowieka zafascynowanego możliwościami Internetu, który staje się dzisiaj doskonałym narzędziem przekazu polisensorycznego, przydatność papierowego podręcznika, niejednokrotnie grubego, ciężkiego (stąd w żargonie

${ }^{31}$ J. Bagrowicz, dz. cyt., s. 35.

${ }^{32}$ Por. J. Szpet, dz. cyt., s. 251.

${ }^{33}$ Por. tamże.

${ }^{34}$ Por. Komisja Wychowania Katolickiego Konferencji Episkopatu Polski, Zasady oceniania osiagnięć edukacyjnych z religii rzymsko-katolickiej w szkotach, „Katecheta” 52 (2008) nr 10, s. 4.

${ }^{35}$ Por. P. Tomasik, dz. cyt., s. 258.

${ }^{36}$ Por. tamże, s. 258. W praktyce szkolnej wykorzystuje się dzisiaj wiele podręczników do nauki religii. Poszczególne funkcje realizuje się w nich w różnych proporcjach, co pozwala z kolei określić kilka typów podręczników. P. Tomasik za W. Okoniem dzieli je na: podręczniki uniwersalne, podręczniki systematyczne, podręczniki do ćwiczeń i zajęć praktycznych oraz podręczniki programowe; por. tamże, s. 265-266. 
uczniowskim często nazywanego „cegłą”), mało atrakcyjnego, budzi już pewne wątpliwości.

Można zapytać: Czy wskazane przez nas funkcje może spełniać tylko papierowy podręcznik? Odpowiedź brzmi na pewno nie. Czy zatem podręcznik musi być koniecznie książką, skoro najważniejsze jest nie to, na jakim nośniku jest zapisany, ale jaka jest jego treść? Odpowiedź brzmi nie, ponieważ postępujący w polskich szkołach od kilku lat proces informatyzacji ${ }^{37}$ stwarza nowe możliwości dla wykorzystania komputerów i Internetu także na lekcjach religii. Czy uczeń przychodzący na lekcję religii z laptopem zamiast z książką i zeszytem to futurystyczne marzenie, czy niedaleka przyszłość? A może, jak zauważył R. Podpora, „postępująca szerokim frontem edukacja informatyczna zapewne w niedalekiej przyszłości przeniesie się do sal lekcyjnych, gdzie Internet stanie się elementem pracy ucznia na wzór dzisiejszego podręcznika do matematyki, nauki religii, języka polskiego itp." ${ }^{38}$. Jak miałby wówczas wyglądać taki e-podręcznik? W dalszej części naszych rozważań będziemy starli się odpowiedzieć na to pytanie.

\section{E-KSIĄŻKA ALTERNATYWĄ DLA PAPIEROWEGO PODRĘCZNIKA DO NAUKI RELIGIl}

W poszukiwaniu odpowiedzi na postawiony wyżej problem należy uwzględnić opisane już funkcje podręcznika oraz oczekiwania uczniów, aby przekaz prawd wiary na lekcjach religii był:

- ciekawy,

- aktywizował,

- oddziaływał polisensorycznie,

- dostosowany był do mentalności młodzieży,

- wykorzystywał ich naturalne predyspozycje.

${ }^{37}$ Zob. Ministerstwo Nauki i Informatyzacji, Strategia kierunkowa rozwoju informatyzacji Polski do roku 2013 oraz perspektywiczna prognoza transformacji społeczeństwa informacyjnego do roku 2020, Warszawa 24.06.2005,[dostęp27.08.2010],http://www.ukie. gov.pl/HLP/files.nsf/0/61B9E65B9496C453C125721F003DCC0E/\$file/Strategia_kierunkowa_rozwoju_informatyzacji_Polski_do_roku_2013.pdf.

${ }^{38}$ R. Podpora, Wstęp, w: red. tenże, Wyzwania wspótczesnej edukacji, E-nauczanie, Lublin 2006, s. 5. 
W odniesieniu do podręcznika do nauki religii dla młodzieży (gimnazjum i szkoły ponadgimnazjalne) można zaproponować:

1. Podręcznik na płycie CD.

2. Podręcznik w wersji e-book.

3. Tworzenie przez katechetów własnych strony WWW pod kątem podręcznika.

4. Tworzenie portali diecezjalnych dla katechetów.

Podręcznik na płycie CD lub w wersji e-book stanowi niewątpliwie pewną alternatywę dla tradycyjnej książki, aczkolwiek w obecnej sytuacji, kiedy wielu uczniów nie posiada jeszcze swojego komputera i dostępu do Internetu, nie może być powszechnie stosowany. Umieszczenie treści papierowego podręcznika na innym nośniku tylko w nieznacznym stopniu „uatrakcyjni” przekaz religijny, ponieważ nadal taki podręcznik nie oddziałuje polisensorycznie.

Warto w tym miejscu przypomnieć, że nauczanie polisensoryczne to nauczanie, w którym angażuje się wiele zmysłów tzn. słuch, wzrok, dotyk i kinestezję. U podstaw takiego nauczania przyjmuje się założenie, że skuteczny proces nauczania-uczenia się musi być oparty o jednoczesne rozwijanie funkcji językowych, funkcji spostrzeżeniowych: wzrokowych, słuchowych, dotykowych oraz współdziałanie między tymi funkcjami (integracja percepcyjno-motoryczna). W nauczaniu polisensorycznym ważne jest, aby przekazywane uczniom informacje były odbierane wielokanałowo, czyli za pomocą różnych zmysłów, ponieważ wiedza przekazywana wielosensorycznie jest bardziej kompletna. Powszechnie wiadomo, że wśród naszych uczniów są osoby o różnych preferencjach sensorycznych. Naukowcy coraz częściej zwracają uwagę na indywidualne style uczenia się, nie wszyscy bowiem przyjmują i zachowują w pamięci wiadomości $w$ ten sam sposób. Jednym przychodzi to łatwiej, innym trudniej, dlatego tradycyjny sposób nauczania-uczenia się oparty często tylko na słownym przekazie, nie zawsze się sprawdza. Możliwości przekazu polisensorycznego daje z pewnością Internet, o ile zostanie w tym celu dobrze wykorzystany.

Wykorzystanie Internetu dla celów katechetycznych może odbywać się między innymi przez tworzenie przez katechetę własnej strony WWW pod kątem podręcznika. Model taki, zaproponowany przez R. Podporę, „zakłada, że uczniowie mają dostęp do Internetu i mogą sięgać po zasoby wiedzy zgromadzone przez katechetę. Tam mogą znaleźć: wyjaśnienie, pogłębienie wiedzy, inny sposób przedstawienia tej samej treści, przygotowanie do nowej lekcji, podjęcie dyskusji na tematy omawiane na 
lekcjach itp. Katecheta decyduje ostatecznie o akcentach nauczania i po jakie materiały odeśle uczniów do Internetu" ${ }^{\prime \prime 39}$. Budowanie przez nauczyciela własnej strony internetowej daje możliwość nie tylko zaciekawienia uczniów lekcją religii, głębsze poznanie intelektualne i emocjonalne, ale także okazję kontaktu z młodzieżą poza zajęciami szkolnymi za pomocą komunikatorów: gadu-gadu, e-mail, czat, skype ${ }^{40}$.

Własna strona WWW katechety, której treść jest skorelowana z treścią podręcznika, daje także wielorakie możliwości jej wykorzystania podczas lekcji religii, o ile sala lekcyjna wyposażona zostanie $\mathrm{w}$ tablicę interaktywną. Wzajemne powiązanie treści internetowych $\mathrm{z}$ treściami podręcznika pozwala utrwalać najważniejsze zagadnienia także poza lekcją, ponieważ młodzież w domu chętniej zagląda do Internetu aniżeli do podręczników. Minusem jest to, iż katecheta musi sam budować taką stronę, na co potrzebuje nie tylko pewnych umiejętności, ale także dużo czasu, bardzo dobrej znajomości treści podręcznika i oczywiście kreatywności. Dyskusyjną pozostaje autoryzacja treści takiej strony przez władzę kościelną, o ile spełniać ma ona funkcje podręcznika. Kodeks prawa kanonicznego nakazuje bowiem, aby katechizmy oraz inne pisma służące do katechizacji lub ich przekłady posiadały aprobatę ordynariusza miejsca oraz zaleca, aby książki „chociaż nie są używane jako podręczniki, jak również pisma o treści szczególnie dotyczącej religii lub dobrych obyczajów, zostały poddane osądowi ordynariusza miejsca"41.

Ze względu na powyższe, optymalnym rozwiązaniem - jak nam się wydaje - jest budowanie witryny diecezjalnej przez zespół katechetów pod merytorycznym nadzorem Wydziału Katechetycznego Kurii Biskupiej lub Diecezjalnego Centrum Katechetycznego, której treści zostaną powiązane z treściami podręczników dla poszczególnych klas gimnazjum i szkół ponadgimnazjalnych. Powstanie takich stron, co należy podkreślić, nie może jednak oznaczać - przynajmniej do momentu ogólnego dostępu młodzieży do Internetu - usunięcia z lekcji religii papierowych podręczników. Portale katechetyczne wydają się być bardzo potrzebna tym bardziej, iż dzisiaj w wielu szkołach likwiduje się tradycyjne tablice, a wprowadza interaktywne.

W odniesieniu do funkcji informacyjno-poznawczej, Internet może dobrze spełniać pomocniczą rolę wobec tradycyjnych, papierowych pod-

${ }^{39}$ Tenże, Uzupetniajaca funkcja Internetu w nauczaniu religii, w: red. tenże, Wyzwania wspótczesnej, s. 29.

${ }^{40}$ Por. tamże.

${ }^{41}$ Kodeks prawa kanonicznego, Poznań 1984, kan. 827 § 1 i 3. 
ręczników, które "grzeszą często przeładowaniem treści, przez to samo zniechęcają ewentualnych odbiorców" ${ }^{\prime \prime 2}$. Treść przekazywanych na lekcjach religii informacji trzeba opierać na autentycznych źródłach - Piśmie Świętym i dokumentach Kościoła, które powinny być interpretowane zgodnie z najnowszą wykładnią teologiczną. Źródła te dostępne są w Internecie na stronie Stolicy Apostolskiej i wielu portalach katolickich np. Opoce. Stąd też można w przyszłości pominąć w podręcznikach wiele wypisów źródłowych, które powodują, iż często jest on zbyt przeładowany treścią, zbyt gruby i ciężki, a na portalach diecezjalnych umieszczać linki do odpowiednich tekstów źródłowych, to znaczy dokumentów Magisterium Kościoła. Wymagałoby to oczywiście ze strony nauczycieli religii pewnego wysiłku i zaangażowania, odnalezienia tych tekstów oraz uporządkowania według treści programowych dla poszczególnych klas.

Funkcję badawczą oraz funkcję samokształceniową pełnić mogą zamieszczone na portalu diecezjalnym webquestety nawiązujące do kluczowych zagadnień poruszanych $\mathrm{w}$ poszczególnych klasach. Webquest jest nowatorską metodą pracy z uczniami wykorzystującą technologię informatyczną. Polega ona na indywidualnej pracy ucznia, poszukującego przede wszystkim informacji w Sieci, aby następnie w grupach tematycznych opracować wspólnie analizowany problem. Metoda nakierowana jest na wyszukiwanie, w którym większość informacji pozyskiwana jest w sposób interaktywny i pochodzi z zasobów internetowych, do których poprzez odpowiednie linki może odsyłać między innymi portal diecezjalny. Webquest jest efektywniejszy w nauczaniu od tradycyjnych metod, ponieważ zawiera wiele czynników motywujących do uczenia się między innymi poprzez możliwość wcielania się przez uczniów w różne role np. naukowców, detektywów, reporterów oraz daje możliwość udziału młodzieży $\mathrm{w}$ zainscenizowanych sytuacjach według zaproponowanych przez katechetę scenariuszy ${ }^{43}$.

Z kolei funkcję kontrolną pełnić mogą między innymi zamieszczone na portalu quizy, zadania, zagadki, a funkcję inicjacyjno-wychowawczą blog i forum dyskusyjne, które mogą stać się miejscami, gdzie uczniowie spotykać będę ciekawych ludzi, prawdziwych świadków Jezusa Chrystusa. Realizacji funkcji praktycznej (operacyjnej) mogą dobrze służyć umieszczone na portalu informacje (stale aktualizowane) wskazujące na

${ }^{42}$ J. Bagrowicz, dz. cyt., s. 34.

${ }^{43}$ Por. Sabina Furgol, Nowe metody i formy pracy, [dostęp 27.08.2010], http:// webquest.furgol.org/. 
to, w jaki sposób młodzież może podjać służbę na rzecz drugiego człowieka, zarówno we wymiarze diecezjalnym jak i parafialnym.

\section{ZAKOŃCZENIE}

Z powyższych dociekań nie wynika bynajmniej, że na tradycyjny, papierowy podręcznik do nauki religii należy patrzeć z nieufnością, jak na narzędzie bezużyteczne dla szkolnej katechezy. Podręcznik taki jest nadal potrzebny, aczkolwiek należy przypuszczać, że za kilka lat zostanie on zastąpiony nową formą, na przykład e-książką. Dzisiejsza cywilizacja naukowo-techniczna, a zwłaszcza szybki rozwój środków informatycznych stawiają przed katechetą nowe możliwości w zakresie „uatrakcyjnienia” przekazu wiary oraz dostosowania go do potrzeb i mentalności ludzi XXI wieku. Dlatego należy bez wątpienia docenić Internet i możliwości jakie on daje, niemniej jednak nie można być także ślepym na niebezpieczeństwa, jakie ze sobą niesie.

Potrzebne są dzisiaj różne rodzaje podręczników, również takie, które odważnie otwierałyby się na przyszłość, na konieczność dawania wyrazu wierze w nowej formie. Język takich podręczników do nauki religii powinien być przede wszystkim narracyjny i głęboko biblijny w swojej inspiracji, nie wystarczą bowiem tylko cytaty z Pisma Świętego czy Katechizmu Kościoła Katolickiego. Uczniowie, zwłaszcza młodzież, nie powinni być tylko „biernymi” odbiorcami podręcznika, ale także aktywnymi uczestnikami w jego tworzeniu i korzystaniu z niego. Możliwości takie, jak się wydaje, daje "skorelowanie” treści podręcznika z zasobami Internetu.

\section{QUEL MANUEL POUR L'ENSEIGNEMENT DE LA RELIGION POUR LA JEUNESSE AU XXIÈME SIÈCLE?}

\section{RÉSUMÉ}

La question des manuels pour l'enseignement de la religion dans l'école polonaise est discutée depuis quelques années parmi les théoriciens et les praticiens de catéchèse. L'introduction dans l'année scolaire 2009/2010 de la nouvelle Base de l'éducation générale a entraîné le besoin d'élaborer une nouvelle Base de programme du catéchèse de l'Eglise catholique en Pologne et aussi de Programme de l'enseignement de la religion, ce qui implique par la suite la necessité d'éditer de nouveaux manuels. 
La question d'un manuel scolaire sur l'enseignement de la religion pour la jeunesse est donc très actuelle et justifiée.

Dans la recherche de réponse à la question posée dans le titre de l'article Quel manuel pour l'enseignement de la religion pour la jeunesse au XXIème siècle? Beata Bilicka tient compte du fait qu'on vit dans une grande époque de technologies d'information, dans une époque ou Internet qui se développe sans cesse, a une grande influence sur le mode de vie des jeunes générations, sur la façon dont elles apprennent, communiquent et collaborent. L'auteur présente ses réflexions en quatre parties. Dans la première partie, elle indique l'un de conditionnement important de l'enseignement contemporain de la religion, tel que l'apparition de l'antipathie des élèves envers l'utilisation des livres en papier. Ensuite, elle décrit les fonctions basiques d'un manuel traditionnel afin d'indiquer dans la partie suivante - en se référant à ces fonctions - à la possibilité d'élaborer une nouvelle forme de livre pour l'enseignement de la religion pour la jeunesse en profitant des possibilités que donnent l'ordinateur et Internet. Le tout couronne une brève conclusion. 